\title{
Penerapan Pembelajaran Siklus Belajar (Learning Cycle 5e) Terhadap Hasil Belajar IPA Siswa Kelas VI SDN 007 Kotabaru Kecamatan Keritang
}

\author{
Dina Liana ${ }^{1}$ \\ ${ }^{1}$ Pendidikan Guru Madrasah Ibtidaiyah, Stai Auliaurrasyidin, Tembilahan Riau, Indonesia \\ *Corresponding author: dinaliana2211@gmail.com
}

\begin{abstract}
Abstrak
Penelitian ini bertujuan untuk meningkatkan hasil belajar biologi siswa kelas VI SDN 007 Kotabaru Tahun Ajaran 2017/2018 dengan menggunakan model pembelajaran Learning Cycle 5 E. Penelitian ini dilaksanakan pada tanggal 22 November 2017 sampai 02 Januari 2018. Subjek penelitian adalah siswa kelas VI SDN 007 Kotabaru yang berjumlah 20 orang siswa, terdiri dari 10 orang siswa laki-laki dan 10 orang siswa perempuan. Penelitian ini merupakan penelitian tindakan kelas (PTK). Pengolahan data menggunakan tes hasil belajar. Teknik analisis data yang digunakan adalah teknik analisis deskriptif yang bertujuan untuk memperoleh gambaran hasil belajar siswa dengan menggunakan Learning Cycle 5 E. Analisis deskriptif tentang hasil belajar siswa yang dilakukan sebanyak 2 siklus terdiri atas 6 kali pertemuan tatap muka dan 2 kali pertemuan digunakan untuk ujian blok. Diperoleh data ketuntasan klasikal siswa sebelum PTK adalah 70\%, dan mengalami peningkatan sebesar $25 \%$ menjadi $95 \%$ pada siklus I dan pada siklus II kembali mengalami peningkatan sebesar 5\% menjadi $100 \%$. Ketuntasan nilai KI sebelum PTK $70 \%$, pada siklus I meningkat sebesar 25\% menjadi 95\%, dan pada siklus II mengalami peningkatan sebesar 5\% menjadi 100\%. Dapat disimpulkan bahwa penerapan pembelajaran Learning Cycle dapat meningkatkan hasil belajar IPA siswa kelas VI SDN 007 Kotabaru.
\end{abstract}

Kata Kunci: Learning, Cycle 5 E, Hasil, Belajar

\section{PENDAHULUAN}

Salah satu factor utama dalam proses pembelajaran yang menentukan mutu pendidikan adalah guru. Gurulah yang berada di garda terdepan dalam menciptakan kualitas sumber daya manusia. Guru berhadapan langsung dengan peserta didik di kelas melalui proses belajar mengajar. Di tangan gurulah akan dihasilkan peserta didik yang berkualitas baik secara akademis, skill (keahlian), kematangan emosional dan moral serta spiritual. Dengan demikian akan dihasilkan generasi masa depan yang siap hidup dengan tantangan zamannya. Oleh karena itu diperlukan sosok guru yang mempunyai kualifikasi, kompetensi, dan dedikasi yang tinggi dalam menjalankan tugas profesionalnya (Kunandar, 2009: 40). 
Hasil observasi dan wawancara penulis dengan guru IPA yang mengajar di kelas VI SDN 007 Kotabaru Kecamatan Keritang, diperoleh informasi yaitu : (a) Kurang bervariasinya metode pembelajaran, (b) aktivitas siswa kurang maksimal dalam belajar, (c) $30 \%$ siswa masih menggunakan lembar kerja siswa (LKS) sebagai sumber belajar, (d) Hasil belajar siswa 29,16\% berada di bawah kriteria ketuntasan minimal (KKM) yang ditentukan yaitu 75 .

Berdasarkan kondisi di atas menuntut adanya perubahan dan perbaikan dalam usaha memperbaiki hasil belajar siswa. Salah satu pembelajaran yang dapat meningkatkan hasil belajar siswa dalam belajar IPA yaitu melalui pembelajaran siklus belajar (Learning Cycle 5E). Model Learning Cycle 5E adalah model pembelajaran yang terdiri fase-fase atau tahap-tahap kegiatan yang diorganisasikan sedemikian rupa sehingga siswa dapat menguasai kompetensi-kompetensi yang harus dicapai dalam pembelajaran dengan jalan berperan aktif. Adapun fase-fase siklus belajar adalah yaitu: engagement (mengajak), exploration (eksplorasi), explanation (menjelaskan), elaboration (memperluas) dan evaluation (evaluasi).

Adapun karakteristik siklus belajar (Learning Cycle 5E) adalah setiap fase siklus belajar benar-benar mencerminkan pengalaman belajar yang dilakukan siswa dalam mengkonstruksi dan mengembangkan pemahaman konsep mereka. Selain itu model siklus belajar telah memerikan suatu format yan adaptable bagi beragam konteks pengajaran mulai dari jenjang pendidikan dasar, menengah hingga perguruan tinggi, serta menekankan pada pemberian pengalaman konkret bagi siswa agar memperoleh pemahaman, pengembangan dan transfer konsep-konsep sains. ${ }^{1}$

Model siklus belajar (Learning Cycle 5E) berorientasi pada konstruktivisme yang sangat memperhatikan pengalaman dan pengetahuan awal siswa serta bertujuan untuk meningkatkan pemahaman konsep siswa. Oleh karena itu pada setiap fase pembelajaran guru dituntut untuk menciptakan kondisi pembelajaran yang beranjak dari isu-isu sains yang relevan dengan lingkungan siswa, memicu proses dise-kuilibrium-ekuilibrium pada diri siswa, serta member kesempatan kepada siswa untuk berinteraksi dengan orang lain dalam mengemukakan dan mengembangkan pemahamannya tentang fenomena sains. ${ }^{2}$

Pembelajaran model siklus belajar (Learning Cycle 5E) memiliki kelebihan yaitu, 1. Meningkatkan motivasi belajar karena siswa dilibatkan secara aktif dalam proses pembelajaran, 2. Lebih berpeluang untuk menyampaikan pendapat dan gagasan, 3. Dapat menumbuhkan kegiatan belajar 4. Pembelajaran menjadi lebih bermakna. ${ }^{3}$

Berdasarkan masalah yang dikemukan di atas, peneliti melakukan penelitian dengan judul "Penerapan Pembelajaran Siklus Belajar (Learning Cycle 5E) Terhadap Hasil Belajar IPA Siswa Kelas VI SDN 007 Kotabaru Kecamatan Keritang

\section{METODE PENELITIAN}

\footnotetext{
${ }^{1}$ Prasetyo dan Fatonah, Pembelajaran Sains, (Penerbit Ombak), 2014, Hlm. 44.

${ }^{2}$ Ibid, Hlm. 46

${ }^{3}$ Rahmawati, Pengembangan Modul Pembelajaran Matematika Model Siklus Belajar (learning cycle)5-E (Skripsi, Universitas Negeri Malang), Hlm. 18
} 
Jenis penelitian penelitian tindakan kelas merupakan kegiatan belajar yang dilakukan di kelas yang bertujuan untuk memperbaiki proses belajar di kelas. Menurut Arikunto, dkk. (2008: 3), ${ }^{4}$ penelitian tindakan kelas (PTK) merupakan pencermatan terhadap kegiatan belajar berupa sebuah tindakan yang sengaja dimunculkan dan terjadi dalam sebuah kelas secara bersama.

Tindakan yang akan diberikan pada penelitian kali ini adalah pembelajaran Siklus Belajar (Learning Cycle 5E). Untuk mengetahui lebih jelas mengenai Penelitian Tindakan Kelas, dapat dilihat desain penelitian berikut.

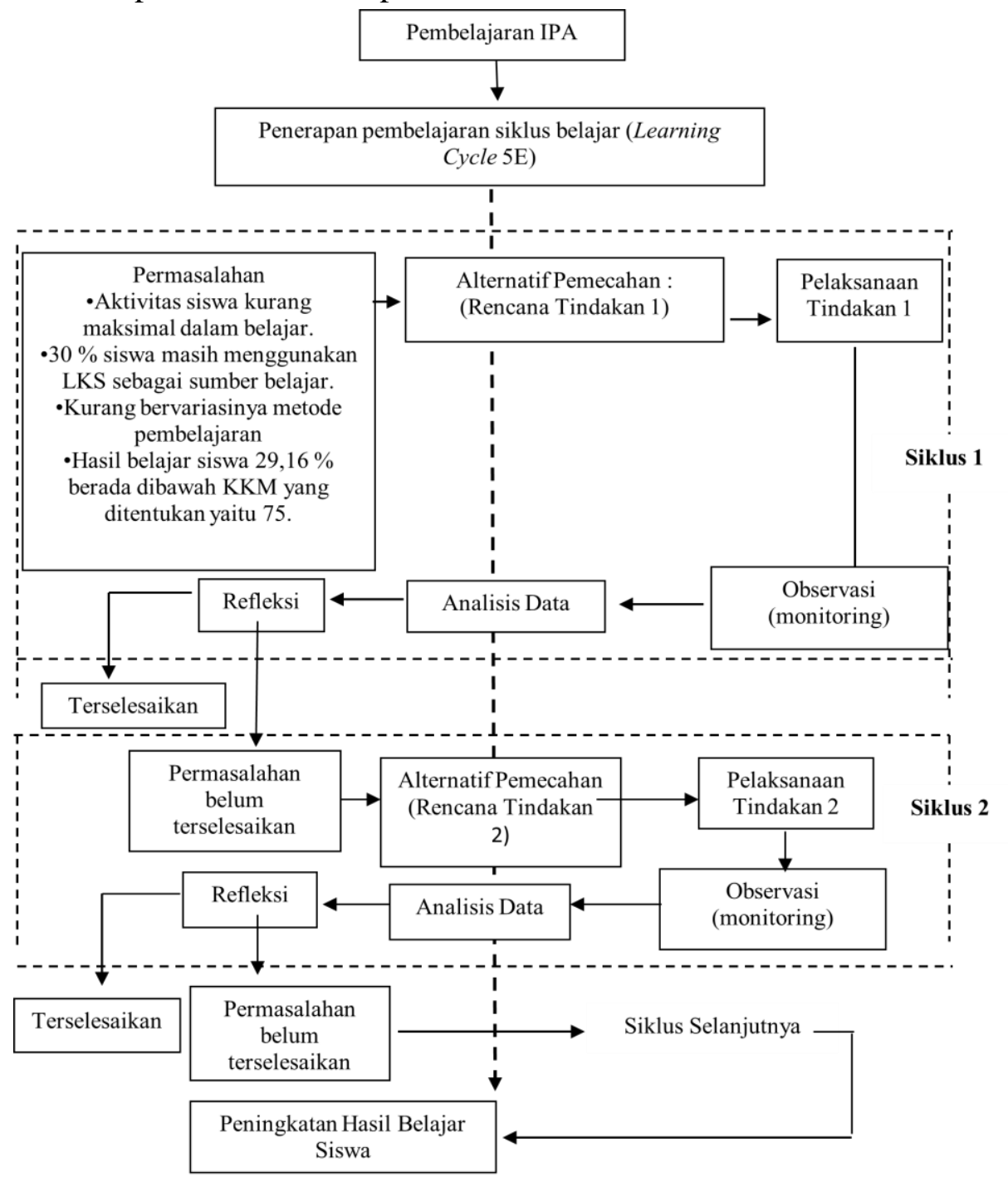

Gambar 1. Modifikasi Design Penelitian Tindakan Kelas Menurut Dave Ebut

Teknik pengumpulan data dalam penelitian ini dilakukan dengan persiapan membuat perangkat pembelajaran dan instrumen pengumpulan data.

${ }^{4}$ Arikunto, Penelitian Tindakan Kelas (Bumi Aksara) Hlm.3. 


\section{Perangkat Pembelajaran Guru}

Perangkat pembelajaran guru terdiri dari:

a. Standar Isi: yaitu struktur kurikulum tingkat satuan pendidikan pada jenjang pendidikan dasar dan menengah.

b. Silabus: yaitu perangkat pembelajaran di dalamnya terdapat identifikasi, standar kompetensi, kompetensi dasar, indikator, materi pokok dan uraian materi, kegiatan pembelajaran, alokasi waktu dan sumber/alat/bahan.

c. Rencana Pelaksanaan Pembelajaran (RPP): yaitu pedoman yang disusun secara sistematis oleh penulis berisikan langkah-langkah panyampaian materi pembelajaran sesuai dengan rincian waktu yang telah ditentukan untuk satu kali pertemuan.

d. Lembar Kegiatan Peserta Didik (LKPD): yaitu suatu pedoman yang disusun peneliti yang berisikan langkah-langkah kegiatan yang harus dilakukan oleh peserta didik

e. Lembar kunci jawaban Lembar Kegiatan Peserta Didik (LKPD)

f. Buku Panduan Siswa: yaitu buku pegangan yang digunakan siswa sebagai pedoman dalam pembelajaran.

g. Kisi-kisi Penulisan Soal

h. Soal PH

i. Kunci Jawaban soal PH

\section{Instrumen Pengumpulan Data}

Pengumpulan data dalam penelitian ini di lakukan dengan dua cara yaitu:

a. Penilaian Pengetahuan Pemahaman Konsep (PPK/ Kognitif ) dikumpulkan data dari nilai pekerjaan rumah (PR), nilai quis tertulis (QT) dan ujian penialian harian $(\mathrm{PH})$.

b. Penilaian Kinerja Ilmiah (KI/ Psikomotorik) siswa diambil dari nilai portofolio (LKPD + Kliping) serta nilai unjuk kerja (diskusi + Presentasi kelompok) dan praktikum.

Data yang diperoleh dianalisis dengan menggunakan teknik analisis data deskriptif. Kuantitatif. Data yang diolah adalah data hasil belajar siswa dan kinerja ilmiah siswa.

Teknik analisis data deskriptif yang digunakan pada penelitian ini bertujuan untuk mendeskripsikan hasil belajar IPA siswa setelah diterapkannya model pembelajaran siklus belajar (Learning Cycle 5E). analisis data hasil pencapaian hasil belajar biologi siswa dilakukan dengan melihat: a) daya serap, b) ketuntasan individu dan c) ketuntasan klasikal.

1. Daya serap

Untuk mengetahui daya serap siswa dihitung dengan menggunakan rumus sebagai berikut:

Daya serap $=\underline{\text { Jumlah skor yang diperoleh siswa }} \times 100$

Jumlah skor maksimum 
Penentuan kriteria dan kategori daya serap siswa dapat terlihat pada Tabel 1 berikut.

Tabel 1. Kriteria dan kategori daya serap siswa

\begin{tabular}{cc}
\hline Skor $(\%)$ & Kategori \\
$91-100$ & Sangat baik \\
$81-90$ & Baik \\
$75-80$ & Cukup \\
$\leq 75$ & Kurang \\
\hline
\end{tabular}

Sumber: Modifikasi sesuai KKM sekolah

\section{Ketuntasan Individu Siswa}

Berdasarkan kurikulum SDN 007 Kotabaru Kecamatan Keritang yang telah ditetapkan dalam kriteria ketuntasan minimal (KKM) pada mata pelajaran IPA bahwa siswa dikatakan tuntas dalam belajar apabila telah mencapai $\mathrm{KKM} \geq 75$.

3. Ketuntasan Klasikal

Menurut Direktorat Pembinaan Sekolah Menengah Atas suatu kelas dinyatakan tuntas belajar jika sekurang-kurangnya $85 \%$ dari siswa tuntas belajar. Ketuntasan klasikal dapat dihitung dengan menggunakan rumus:

$$
\mathrm{KK}=\frac{J S T}{J S} \times 100
$$

Keterangan:

$\mathrm{KK}=$ Persentase ketuntasan belajar klasikal

JST = Jumlah siswa yang tuntas

JS = Jumlah seluruh siswa

\section{HASIL DAN PEMBAHASAN}

Berdasarkan data yang diperoleh dari hasil penelitian yang dianalisis secara deskriptif setelah menerapkan pembelajaran learning cycle 5E di kelas VI SDN 007 Kotabaru, maka diketahui bahwa terdapat perbedaan hasil belajar siswa pada setiap kali pertemuan pada siklus I. Hal ini dapat dilihat pada siklus I pertemuan ke-2 dalam PTK hasil belajar siswa yaitu dengan rata-rata daya serap siswa 95\% dengan kategori sangat baik. Hal ini disebabkan siswa sudah mulai termotivasi, terbiasa dan aktif dengan pembelajaran Learning cycle 5E sehingga siswa mudah dalam memahami materi pelajaran.

Pertemuan ke-1 dalam PTK dengan rata-rata siswa yaitu $85 \%$ dengan kategori baik. Hal ini disebabkan karena pada pertemuan ke-1 siswa masih belum terbiasa dengan pembelajaran learning cycle $5 \mathrm{E}$ dan siswa juga belum termotivasi untuk belajar karena pada pertemuan ke-1 belum diberikan hadiah bagi kelompok yang nilai nya tertinggi. Berdasarkan pengamatan peneliti, untuk siklus I telah berjalan dengan cukup baik. Siswa tampak termotivasi belajar berkelompok karena di tiap akhir pelajaran ada penghargaan kelompok. Tetapi ada beberapa hal yang tidak sesuai dengan perencaanaan, yaitu : 
1) Masih ada siswa yang hasil belajarnya kurang dari 75 , kelemahan siswa terlihat dari hasil penilaian harian 1. Hal ini disebabkan sebagian siswa kurang membaca dan kurang memahami materi di rumah dan selama ini siswa juga masih terbiasa menerima langsung pelajaran dari guru. Sedangkan proses pembelajaran learning cycle 5E mengharapkan kelas berpusat pada siswa sehingga siswa masih kurang berpartisipasi dalam diskusi kelas.

2) Siswa belum terbiasa belajar kelompok, sehingga kerjasama dan tanggung jawab dalam kelompok masih kurang.

3) Siswa masih belum banyak yang mau berpartisipasi dalam praktikum, sehingga seringkali guru harus memaksa siswa untuk melaksanakan praktikum.

Rencana peneliti untuk memperbaiki tindakan selanjutnya adalah;

1) Guru mengingatkan kembali dan selalu menggali pengetahuan awal siswa dengan pertanyaan-pertanyaan terhadap materi yang telah dipelajari pada pertemuan sebelumnya yang berkaitan dengan materi yang dipelajari.

2) Memotivasi dan membimbing siswa secara cermat, agar seluruh siswa terlibat dalam melaksanakan praktikum dan bekerjasama yang baik supaya siswa lebih aktif dalam belajar.

Hadiah dapat dikatakan sebagai motivasi, karena siswa akan berlomba-lomba untuk mendapatkan penghargaan/hadiah tersebut. ${ }^{5}$ Keberhasilan siswa dapat ditentukan oleh motivasi belajar yang dimilikinya. Siswa yang memiliki motivasi belajar tinggi cenderung prestasinya pun akan tinggi pula, sebaliknya siswa yang motivasi belajarnya rendah, akan rendah pula prestasi belajarnya. ${ }^{6}$

Dalam proses pembelajaran motivasi merupakan salah satu aspek dinamis yang sangat penting. Model struktur penghargaan kooperatif telah dapat meningkatkan penilaian siswa pada belajar akademik, dan perubahan norma yang berhubungan dengan hasil belajar ${ }^{7}$ Tujuan penting lain dari pembelajaran kooperatif adalah untuk mengajarkan kepada siswa keterampilan kerjasama dan kolaborasi.

Berdasarkan data hasil belajar siswa pada siklus 2 yang dianalisis secara deskriptif, maka diketahui bahwa rata-rata hasil belajar kognitif IPA siswa tertinggi pada pertemuan ke-5 kuis 4 yaitu $92 \%$ dengan kategori sangat baik. Hal ini disebabkan siswa sudah termotivasi dan sudah lebih memahami pembelajaran Learning Cycle 5E. Pertemuan ke-7 kuis 6 rata-rata daya serap hasil belajar siswa paling rendah pada siklus 2 yaitu $85 \%$ dengan kategori baik. Hal ini karena dipengaruhi oleh faktor-faktor seperti cuaca dan keributan sehingga mempengaruhi fokus siswa yang sedang mengadakan kuis.

\footnotetext{
${ }^{5}$ Sardiman, Interaksi dan Motivasi Belajar Mengajar, (Raja Grafindo Persada), 2011. Hlm. 92.

${ }^{6}$ Sanjaya, Strategi Pembelajaran Berorientasi Standar Proses Pendidikan.(Persada Media Group), 2011, Hlm. 97.

${ }^{7}$ Amri dan Ahmad Proses Pembelajaran Inovatif dan Kreatif dalam Kelas(PT Prestasi Pustakarya)2010, Hlm. 67.
} 


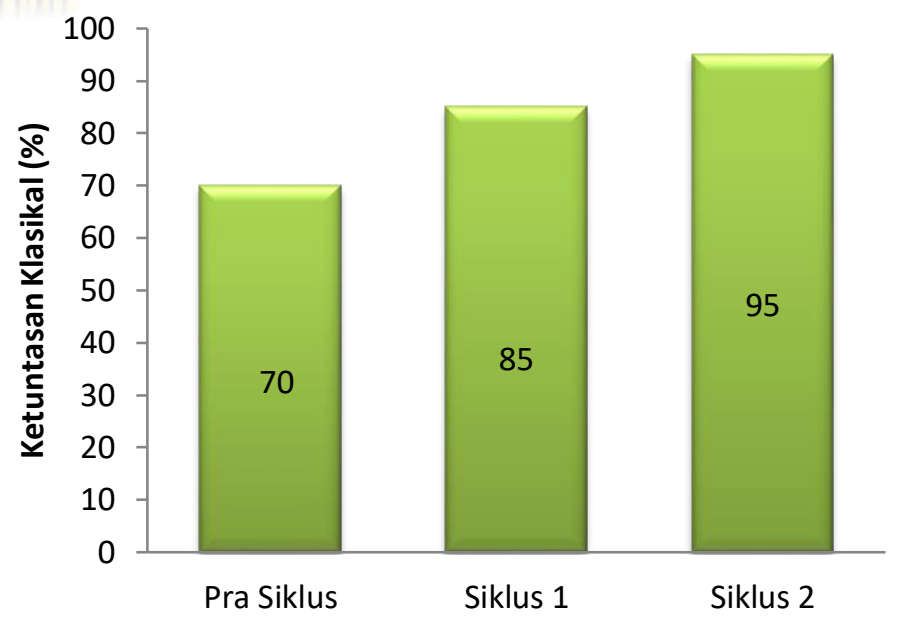

Gambar 2. Perbandingan Ketuntasan Klasikal Pada Nilai Hasil Belajar Kognitif Pra Siklus, Siklus 1 Dan Siklus

Pada ujian penilaian harian siklus 2 rata-rata daya serap hasil belajar kognitif siswa tertinggi dibandingkan dengan ujian penilaian harian siklus I yaitu $85 \%$ dengan pra siklus yaitu $70 \%$. Ini disebabkan pada siklus II ujian penilaian harian diadakan dipagi hari sehingga siswa mudah berkonsentrasi dalam menjawab soal ujian penilaian harian. Pada ujian penilaian harian pra siklus lebih rendah dari siklus 1 dan 2 hal ini disebabkan siswa kurang termotivasi dalam belajar sehingga minat belajarnya berkurang, sementara pada siklus I rata-rata daya serap hasil belajar siswa lebih rendah dibandingkan dengan siklus 2 yaitu $85 \%$. Hal ini disebabkan ujian penilaian harian diadakan pada jam terakhir sehingga siswa tidak konsentrasi dalam menjawab soalnya. Guru mengajar adalah menyediakan kondisi yang kondusif agar masing-masing individu anak didik itu dapat belajar lebih optimal. ${ }^{8}$

Berdasarkan data yang telah dianalisis dengan analisis deskriptif terlihat bahwa penerapan pembelajaran Learning Cycle $5 \mathrm{E}$ dapat meningkatkan hasil belajar psikomotorik IPA siswa kelas VI SDN 007 Kotabaru. Peningkatan ini dapat dilihat dari persentase rata-rata hasil belajar siswa sebelum PTK 70\%, meningkat menjadi 95\% setelah PTK siklus I, sedangkan setelah PTK siklus II hasil belajar kembali mengalami peningkatan menjadi 100\%, maka dapat dijelaskan bahwa rata-rata hasil belajar psikomotorik siswa dari sebelum PTK dengan setelah PTK mengalami peningkatan. Peningkatan hasil belajar psikomotorik pada siklus I adalah sebesar 25\% dibandingkan sebelum PTK, sedangkan dari siklus I ke siklus II terjadi peningkatan sebesar $5 \%$. Dengan peningkatan setelah PTK maka dapat dikatakan bahwa model Learning Cycle 5E dapat memberikan keuntungan baik pada siswa kelompok bawah maupun kelompok atas, atas kerjasama menyelesaikan tugas-tugas akademik, siswa kelompok atas akan menjadi tutor bagi siswa kelompok bawah. Dalam proses tutorial ini, siswa kelompok atas akan meningkat kemampuan akademiknya karena memberi pelayanan sebagai tutor

${ }^{8}$ Sardiman, Op.Cit. Hlm. 119 
membutuhkan pemikiran lebih dalam tentang hubungan ide-ide yang terdapat di dalam materi tertentu. Interaksi yang terjadi dalam belajar kooperatif dapat memacu terbentuknya ide baru dan memperkaya perkembangan intelektual siswa. ${ }^{9}$

Ketuntasan hasil belajar psikomotorik setiap individu sebelum PTK dari 20 orang siswa hanya 14 yang tuntas dan terdapat 6 orang siswa yang tidak tuntas. Hal ini disebabkan guru hanya memakai metode ceramah dalam proses pembelajaran sehingga banyak siswa tidak aktif dan termotivasi untuk belajar. Pada siklus I dari 20 orang siswa terdapat 19 orang siswa yang tuntas dan terdapat 1 orang siswa yang tidak tuntas. Hal ini disebabkan siswa sudah mulai termotivasi dan aktif dalam belajar. Sedangkan pada siklus II dari 20 orang siswa semuanya tuntas. Hal ini disebabkan siswa sudah termotivasi dan terbiasa dengan pembelajaran Learning Cycle 5 E. Ketuntasan klasikal sebelum PTK yaitu $70 \%$, pada siklus I ketuntasan klasikal meningkat menjadi $95 \%$ dan PTK siklus II kembali meningkat menjadi 100\%, maka secara klasikal kelas VI SDN 007 Kotabaru telah dikatakan tuntas, hal ini sesuai dengan pendapat Direktorat Pembinaan Sekolah Dasar, bahwa suatu kelas dinyatakan tuntas apabila sekurangkurangnya $85 \%$ dari jumlah siswa yang telah tuntas belajar.

Penilaian psikomotorik siswa pada siklus 1 dan siklus II diambil dari nilai Praktikum dan Pekerjaan Rumah. Nilai Praktikum diambil setiap kali pertemuan. Dapat dilihat pada gambar berikut perbandingan nilai kinerja ilmiah dari pra siklus, siklus 1 dan siklus 2 .

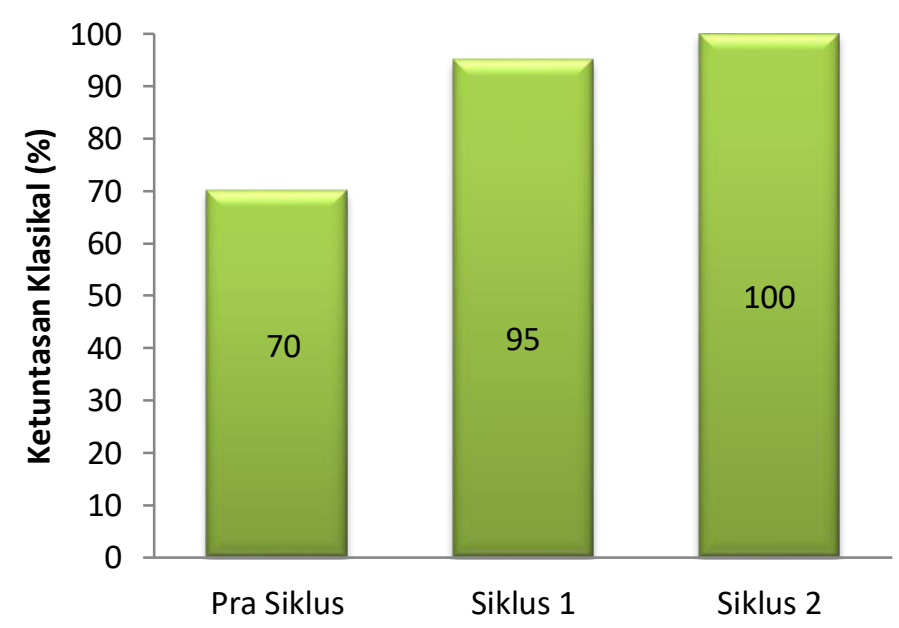

Gambar 2. Perbandingan Ketuntasan Klasikal Pada Nilai Hasil Belajar Psikomotrik Pra Siklus, Siklus 1 Dan Siklus 2

Nilai hasil belajar psikomotorik mengalami peningkatan daya serap sebelum PTK yaitu $70 \%$ meningkat setelah PTK siklus I yaitu $95 \%$ dan kembali meningkat setelah PTK siklus 2 yaitu $100 \%$. Hal ini disebabkan karena siswa antusias dan termotivasi

${ }^{9}$ Trianto, Model-Model Pembelajaran Inovatif Berorientasi Konstruktivistik (Prestasi Pustaka) 2010. Hlm. 62 
dalam pembelajaran Learning Cycle 5 E., sesuai dengan pendapat Hafiah, Lukita dan Siswanto bahwa cyle $5 \mathrm{E}$ adalah model pembelajran yang lebih memberdayakan siswa. ${ }^{10}$

Penghargaan kelompok siklus 1, pada pertemuan ke-1 dan ke-2 merupakan pertemuan yang memiliki kelompok tim super pada Siklus I, yaitu pertemuan ke-1 kelompok 2 dan 5 sedangkan pertemuan ke-2 yaitu kelompok 1 dan 5 . Hal ini disebabkan karena tidak meratanya siswa yang memperoleh nilai baik. Kelompok yang termasuk kategori baik terdapat pada pertemuan ke-4 yaitu kelompok 1,2,3,4 dan 5 Hal ini disebabkan meratanya siswa yang memperoleh nilai baik.

Penghargaan kelompok siklus II pada pertemuan ke-5 dan ke-6 merupakan kategori tim super paling banyak yaitu pertemuan ke-5 kelompok 1 dan 2 sedangakan pertemuan ke-6 yaitu kelompok 2 dan 5. Hal ini disebabkan karena siswa sudah memahami pembelajaran Learning Cycle 5 E sehingga banyak siswa memperoleh nilai baik.

Berdasarkan analisa data dan pengamatan pada siklus II, maka peneliti dapat menyimpulkan bahwa siklus II ini lebih baik daripada siklus 1. Hal ini terlihat dari beberapa hal, yaitu:

1. Pada siklus II ini siswa sudah terbiasa dengan belajar berkelompok. Hal ini terlihat dari keaktifan siswa dalam bekerjasama dan membantu dalam kelompok.

2. Pada saat diskusi dan presentasi siswa sudah banyak yang aktif. Siswa sudah banyak yang bertanya, menjawab dan menyanggah.

3. Siswa sudah mengalami peningkatan pada hasil belajarnya

4. Pada kinerja ilmiah siswa juga turut mengalami peningkatan

5. Karena daya serap dan ketuntasan belajar siswa telah mengalami peningkatan, maka peneliti tidak melanjutkan ke siklus berikutnya.

Jjadi dapat peneliti simpukan bahwa meningkatnya hasil belajar IPA siswa kelas VI SDN 007 Kotabaru disebabkan oleh pembelajaran Learning Cycle 5 E. Hal ini dapat membuat siswa termotivasi untuk belajar, bekerjasama, bertanggungjawab, dan bisa memahami materi pelajaran dengan mudah. Belajar kooperatif dapat mengembangkan tingkah laku kooperatif dan hubungan yang lebih baik antar siswa, dan dapat mengembangkan kemampuan akademis siswa. Siswa lebih banyak belajar dari teman mereka dalam belajar kooperatif daripada guru. ${ }^{11}$

\section{KESIMPULAN DAN SARAN}

Berdasarkan hasil penelitian yang diperoleh dapat disimpulkan bahwa penerapan pembelajaran Learning Cycle 5 E dapat meningkatkan hasil belajar IPA khususnya pada ranah kognitif dan psikomotorik di kelas VI SDN 007 Kotabaru. Pada materi melakukan percobaan untuk menyelidiki hubungan antara gaya dan gerak (model jungkat jungkit,

${ }^{10}$ Hafiah, Lukita dan Siswanto. 2018. Pembelajaran Learning Cycle 5E Berbasis Pengajuan Masalah untuk Meningkatkan Hasil Belajar Siswa Kelas X Pada Topik Trigonometri. Jurnal Matematika Kreatif Inovatif. HIm 57.

${ }^{11}$ Ibid, Hlm. 62. 
katapel/model traktor sederhana energi pegas) dan menyajikan informasi tentang perpindahan dan perubahan energi listrik.

Berdasarkan penelitian yang dilaksanakan penulis dengan penerapan pembelajaran Learning Cycle 5 E penulis menyarankan:

1) Diharapkan kepada guru IPA Kelas VI SDN 007 Kotabaru dapat menjadikan pembelajaran Learning Cycle 5 E sebagai salah satu alternatif model pembelajaran yang dapat meningkatkan hasil belajar IPA siswa.

2) Diharapkan kepada guru yang menerapkan kooperatif agar lebih memaksimalkan untuk membimbing siswa-siswanya agar tidak terjadi keributan.

3) Kegiatan praktikum hendaknya lebih sering dilakukan agar keterampilan siswa dapat terasah dengan baik.

\section{DAFTAR PUSTAKA}

Amri, S. dan Ahmadi, I. K. (2010). Proses Pembelajaran Inovatif dan Kreatif dalam Kelas. PT. Prestasi Pustakarya: Jakarta.

Arikunto, S. Suhardjono dan Supardi. (2008). Penelitian Tindakan Kelas. Bumi Aksara: Bandung.

Dyah, A., \& Istiqomah, N. N. (2016). Model Pembelajaran Learning Cycle 5 E : Mengaktifkan Siswa Pada Materi Suhu dan Perubahannya. Jurnal Penelitian Pendidikan IPA. Issn 2549-2209.

Hafiah, S., Lukita, A., \& Siswono, T. Y. (2018). Pembelajaran Learning Cycle 5E Berbasis Pengajuan Masalah untuk Meningkatkan Hasil Belajar Siswa Kelas X Pada Topik Trigonometri . Jurnal Matematika Kreatif Inovatif , Issn 2442-4218.

Prasetyo Z. K dan Fatonah S. (2014). Pembelajaran Sains. Penerbit Ombak. Yogyakarta.

Sanjaya, W. (2011). Strategi Pembelajaran Berorientasi Standar Proses Pendidikan. Prenada Media Group: Jakarta.

Sardiman. (2011). Interaksi dan Motivasi Belajar Mengajar. RajaGrafindo Persada: Jakarta.

Sugiyono (2011), Metode Penelitian Kuantitatif, Kualitatif dan $R$ \& D, Bandung, Alfabeta.

Trianto. (2010). Mendesain Model Pembelajaran Inovatif Progresif. Prenada Media: Jakarta.

Zulchaidar, I. (2017). Penerapan Learning cycle 5 E Untuk Meningkatkan Prestasi Belajar Siswa SMP Dalam Pemebelajaran IPA. Jurnal Penelitian Pendidikan. issn 2503-1260. 